EASTERN REVIEW 2016, T. 5

Анатолий Круглашов

\title{
Украинская местная демократия: от советского наследия к европейской модели
}

Тема локальной (местной демократии), ее зарождения и развития становится все более важной и востребованной в Европе, да и в общемировых масштабах. Особенно актуальна она для Украины, где происходит болезненный поиск новых форм и содержания государственного управления, путей консолидации общества и восстановления территориальной целостности страны. От того, насколько сильна будет поддержка украинской государственности на местах, как эффективно и устойчиво будет работать система местного самоуправления и на каких основаниях и условиях взаимодействовать с органами государственной власти, в значительной мере, зависит дальнейшие судьбы страны и, в немалой степени, постсоветского пространства.

Исторически в Украине были достаточно сильны традиции локальной демократии, которые с определенной долей достоверности прослеживаются еще со времен Киевской Руси. В частности, ее институциональным воплощением были веча ${ }^{1}$, действовавшие в городах этого государства и влияющие на его политику и развитие в целом ${ }^{2}$. Эти традиции обретают новый смысл и воплощение во время Запорожской Сечи, когда военная демократия украинского казачества становится образцом для формирования казацко-гетманской государственности Украины ${ }^{3}$. Последняя, впрочем, не смогла развиться в модерное и суверенное государство. Она была оконча-

1 П. Гураль, Міські та волосні громади - активні учасники політичного життя Київської Русі, „Вісник Львівського університету. Серія юридична” 2011, Вип. 52, с. 56-63.

2 О. Олійник, Урядування” в літописній традиції Київської Русі, Збірник наукових праць НАДУ, http://www.nbuv.gov.ua/e-journals/DUTP/2011_2/txts/Oliynyk. Pdf (12.11.2015).

3 Р. Губань, Правове регулювання становлення сучасного адміністративно-територіального устрою (від Київської Русі до Гетьманщини), „Науковий вісник Академії муніципального управління" 2009, Вип. 2, с. 22-31. 
тельно уничтожена в начале правления Екатерины $\mathrm{II}^{4}$. Однако, традиции казацких рад, хотя и не были проявлением именно местной демократии, тем не менее, служили важным инструментом политики, позволявшим рядовым казакам влиять на стратегический курс и на кадровую политику этой формы украинской государственности.

Но с расцветом абсолютизма в Российской империи, а также и на украинских землях в Австрийской империи, локальная демократия была уничтожена, сохраняясь разве что на уровне весьма условной выборности сельских старост. При этом, украинские города в Российской империи потеряли остатки Магдебургского права, являвшегося важным правовым основанием и оформлением локальной демократии во многих городах и городских поселениях Украины ${ }^{5}$. К счастью, для западно-украинских земель, ее развитие возобновляется тут в результате революции 1848-1849 гг. и, особенно в связи с принятием конституции Австро-Венгрии ${ }^{6}$. С задержкой, но и в Российской империи развиваются попытки формирования основ местного самоуправления, сначала в лице городских дум, а затем и на уровне местных земств ${ }^{7}$. Эти реформы Александра II также внесли свой вклад в институционализацию основ локальной демократии. Но не следует забывать, что земства и городские думы были ограничены высшей властью Российской империи во всех смыслах, в том числе, в своих компетенциях и, кроме того, их создание не распространялось на все украинские земли, а именно Правобережную Украину, большую часть территории бывшей Речи Посполитой. Их правомочность охватывала незначительные сферы местного управления, а со времени контрреформ Александра III была еще более им ограничена ${ }^{8}$.

Если же вести речь о периоде господства советской власти, то рассматривать ее как форму локальной демократии будет вообще неуместно, так как во главу угла государственного устройства „страны Советов”

${ }^{4}$ Г. Макушина, Політична та правова культура населення Гетьманщини XVIII cm. y сучасній icmopiozрафiї, „Наукові праці Миколаївського державного гуманітарного університету імені Петра Могили” 2008, Вип. 75, с. 117-119.

${ }^{5}$ М. Олуйко, В. Олуйко, Украйна на шляху до держави самоврядних територіальних громад, „Університетські наукові записки” 2005, № 1-2, с. 323.

${ }^{6}$ А. Нестеров, Австро-Венгрия как интеграционный проект: опыт для Центрально-Восточной Европь XXI в., „Известия Уральского федерального университета”, Серия 3, Общественные науки, 2013, с. 69-73.

${ }^{7}$ Г. Герасименко, История земского самоуправления, Поволжская академия гос. службы, 2003; В. Абрамов, Демократическая практика российского земства, „Политические исследования" 1995, № 3, с. 145-151.

8 Д. Полещенко, Государственная власть и местное самоуправление в Российской империи и Российской Федерации, „Журнал российского права” 2010, № 11, с. 100-108. 
большевистская власть поставила идею демократического централизма ${ }^{9}$, которая в принципе отрицала любую локальную самодеятельность, кроме как санкционированную властями. Советы на местах являлись по существу подчиненными организационно-распорядительными органами, беспрекословно выполнявшими указания партийных структур, а их представительские функции имели формально-пропагандистский характер, не более того.

Поэтому именно с горбачевской „перестройкой”"10 связано возрождение не только демократических процессов, но и самой локальной демократии как явления и процесса на территории Советского Союза и Украины в том числе. Причем, нужно вспомнить, что первым шагом к перестройке общественно-политического режима со стороны горбачевского, реформаторского крыла коммунистической партии было восстановление некоторых основ локальной демократии, начиная с ее самого низового уровня. Очень важную, хотя и до конца успешную роль сыграло принятие закона „О трудовых коллективах" и проведение на его основе соответствующих выборов. В общем и целом такие усилия были направлены на наполнение более реальным смыслом понятия „народовластия" 11 .

В качестве примера хочу привести лучше всего мне известный опыт проведения таких выборов в Черновицком государственном университете. В 1987 году я был участником расширенного заседания его Ученого совета, который должен был избрать нового ректора университета. И эти выборы проходили как раз в контексте осуществления горбачевских реформ на местах, когда происходила смена руководства через процесс избрания новых руководителей на альтернативной (конкурентной) основе. Подобные процессы тогда происходили во многих других государственных учреждениях. Кандидатов на ключевую должность ректора университета было несколько, но из них два были основными. Первый - проректор по науке проф. Костышин Степан Степанович и, тогда единственный академик Украинской Академии наук в университете Анатычук Лукьян Иванович. Это были два сильных кандидата. Лукьян Иванович, как амбициозный ученый и достаточно авторитарный по стилю руководства лидер, выступил с программой радикальных изменений в университете, требуя от коллектива работать с отдачей, эффективностью и результативностью. Своей задачей он видел жесткую дисциплину и оценку труда коллег по ее результатам. Степан

9 В. Шейнис, Большевистская власть и первая советская Конституция, „Общественные науки и современность” 2012, № 1, с. 109-112.

10 А. Артемов, Образ перестройки в официальной риторике в 1988-1989 годы на примере выступлений М.С Горбачева, ,VECTOR-M” 2014, с. 57-60.

11 О. Шановська, Інтелігениія $i$ влада в Украӥні доби Перебудови: проблема взаємовідносин, „Наукові записки Вінницького державного педагогічного університету імені Михайла Коцюбинського. Серія: Історія” 2009, № 15, с. 155-156. 
Степанович выступил с довольно-таки противоположными предложениями. Его предвыборные обещания можно упрощенно представить как „все будет хорошо, потихоньку, спокойно", без резких движений и радикальных изменений в коллективе и стиле управления им. В результате около $3 / 4$ участников выборов проголосовали за него, а $1 / 4$ проголосовали за радикальные изменения в лице его конкурента. Конечно, на таком единичном примере не стоит делать слишком широких обобщений, но, тем не менее, кое-какие тенденции можно обнаружить и с помощью этого примера.

То есть, горбачевское стремление к восстановлению локальной демократии, основанное на, казалось бы, таком очевидном предположении, что трудовые коллективы лучше знают, каких руководителей им избирать, и они выберут для себя наиболее динамичных и эффективных руководителей, оказалось не столь уж обоснованным. Консервативные тенденции, организационный и кадровый застой уже в начале перестроечных процессов показали сложность осуществления реформ ${ }^{12}$ и динамичных изменений на самом низовом уровне управления, что можно наблюдать и до сих пор, в том числе и на примере ЧНУ. То есть, в значительной степени сами трудовые коллективы, этот предполагаемый оплот локальной демократии, низовой, базисный ее уровень, оказались не столь уж увлечены демократией, и открывающимися ею перспективами изменений, а больше руководимы желанием минимизировать изменения и уберечь себя от излишних хлопот. Это проявление стихийного консерватизма оказалось очень поучительным моментом для автора в понимании новейшей истории становления локальной демократии.

Более заметные изменения в сторону реальных процессов демократизации в политическом смысле, начинаются с выборов 1989 и 1990 года в $\mathrm{CCCP}^{13}$. В последнем случае местные советы избирались уже на альтернативной основе, в условиях идеологического и начавшегося формироваться партийного плюрализма. То есть, когда в Украине начинают появляться оппозиционные по отношению к КПСС политические партии, создаваться «демократические блоки» в местных советах, тогда можно отметить зарождение политических основ локальной демократии. Опять же, уместно напомнить примечательный факт, что оппозиционные по отношению к КПСС политические силы победили только в трех западно-украинских, галицких областях (Львовская, Ивано-Франковская и Тернопольская) $)^{14}$. Они

12 А. Иванченко, А. Любарев, Российские выборы от перестройки до суверенной демократии, Москва 2007, с. 14-16.

${ }_{13}$ В. Согрин, Перестройка: итоги и уроки, „Общественные науки и современность” 1992, № 1, с. 137-138.

14 О. Муравський, Виборча кампанія 1990 року до Верховної Ради УРСР та місцевих органів влади: особливості Західноукраӥнського регіону, „Україна: культурна спадщина, національна свідомість, державність” 2013, Вип. 23, с. 683-689. 
сформировали Галицкую Ассамблею, которую в чем только не обвиняли партийные органы того времени. В прочих же областях Украины партийные кадры остались в большинстве советов ${ }^{15}$. В Черновцах сложилась своеобразная ситуация. В городском совете демократический блок не был в большинстве, но в его состав вошло достаточно много депутатов - более 40 из 110. То есть, это было влиятельное, достаточно консолидированное меньшинство, почти достигавшее половины состава депутатов. Однако, в отличие от областного центра, в областном и районных советах было создано устойчивое консервативное большинство, которое постоянно блокировало любые передовые инициативы. Такой общая ситуация на местном уровне оставалась до 1991 года.

Эти годы представляют интересный для дальнейшего изучения опыт становления локальной демократии, когда она более динамично развивалась в западно-украинской и урбанистической среде и значительно хуже в консервативной среде, в частности, это касается Востока и Центра Украины. Там также были представители демблока, но они были в меньшинстве.

Следующий этап развития локальной демократии связан уже с периодом независимости Украины. Тем не менее, обретение государственной независимости не нужно автоматически связывать ни с общедемократическими тенденциями развития страны, ни с успешным ее прогрессом на локальном и региональном уровне ${ }^{16}$. Все же, важным фактором развития политической системы и местной демократии стали изменения в избирательной системе Украины ${ }^{17}$. Пиком электоральных проявлений локальной демократии по сегодняшний день остаются выборы 1994 года. Тогда системный кризис украинской государственности поставил вопрос о ее дальнейшем существовании. О серьезности ситуации свидетельствовали социальные протесты шахтеров, проявления крымского сепаратизма (частично, закарпатского и буковинского) и, в дополнение ко всему, массовое недовольство граждан деятельностью властных институтов ${ }^{18}$. Все это привело к стремлению к тотальным перевыборам всех уровней власти, включая Президента, Верховной Рады и местных советов. Вследствие такого развития событий на местных выборах впервые граждане получили право

15 Ю. Кузьменко, Партійно-радянська номенклатура в умовах суверенізачії УРСР (березень 1990-серпень 1991 рр.), „Український історичний журнал” 2013, № 4, с. 30-33.

16 К. Ганшина, Становлення ірозвиток системи місиевого самоврядування унезалежній Україні: від авторитаризму до демократї, „Збірник наукових праць Харківського національного педагогічного університету імені Г. С. Сковороди” 2010, Серія 39, с. 41-47.

17 Б. Райковський, Взаємодія виборчої та партійної систем: вітчизняний досвід, „Наукові праці Чорноморського державного університету імені Петра Могили” 2010, Вип. 112, c. 79-82.

18 М. Кармазіна, Демократи, соціалісти й „третя сила” у боротьбі за владу (1991-1994 pp.), „Політичний менеджмент” 2005, № 6, с. 55-56. 
и возможность сформировать всю местную власть. То есть, избрать как глав, так и депутатов сельских, поселковых, городских, районных, областных советов непосредственно. Тем самым был запущен механизм избрания всех должностных лиц, как представительной, так и исполнительной власти на местах.

Однако, сама по себе возможность избрания новых депутатов и руководителей местных советов не означала освобождения местной власти от представителей бывшей номенклатуры и прихода во власть совершенно новых лидеров. Конечно, местная специфика проявляла себе в разных регионах. Так, например, в Черновицкой области с 1990 года председателем областного совета и исполкома был Иван Гнатышин (сейчас он снова посол Украины в Республике Молдова). Понятное дело, что, будучи руководителем и лидером региональной и локальной элиты, он с легкостью обошел своих конкурентов в борьбе за пост главы областного совета, в том числе представителя Республиканской партии Украины Остапа Юрийчука. Он набрал серьезное количество голосов, причем, уже в первом туре.

Но этот относительный триумф местной электоральной демократии длился недолго. Вскоре после избрания Леонида Кучмы новым Президентом Украины, началось систематическое наступление не только на демократию в целом, но и локальную демократию в частности. И после короткого периода действия конституционного договора 1995 года, уже в 1996 году Л. Кучма перешел к консолидации своей личной власти ${ }^{19}$ и к попыткам построения в Украине авторитарного режима ${ }^{20}$, причем именно консолидированного авторитарного режима, каковой устанавливался, к примеру, в Республике Беларусь, РФ и ряде других постсоветских стран.

С тех пор, на мой взгляд, локальная демократия в Украине не получала систематической поддержки государства ни на уровне правового регулирования, ни на уровне институциональных реформ, ни на уровне надлежащего финансирования. А отношения центр-периферия были построены на принципах централизации государственного управления ${ }^{21}$, ведущих, в том числе, к превращению регионов страны в дотационные, не только политически, но и финансово зависимые от воли (и своеволия) центральных властей. И с тех пор, с 1996 года и до Революции Достоинства,

${ }^{19}$ К. Пальшков, Легіслатури Л. М. Кравчука та Л. Д. Кучми як період становлення та затвердження авторитарного іміджу украӥнського президентства, „Актуальні проблеми політики" 2013, Вип. 50, с. 196-199.

${ }^{20}$ О. Долженков, „Політологічні записки”2013, № 7, http://nbuv.gov.ua/j-pdf/Polzap_2013_ 7_5.pdf (13.11.2015).

21 А. Сухорукова, Обласні державні адміністрації: становлення та тенденції розвитку, „Теорія та практика державного управління” 2010, № 3, с. 102-108. 
все главы областных государственных администраций (назначаемые фактически единолично президентами Украины), с разными вариациями, предлагали вниманию сограждан на местах одну и ту же версию объяснения текущего политического момента: „Мы дотационный регион, если бы не поддержка Киева (Кабинета министров, премьер-министра, а еще лучше - лично президента), мы бы вообще пропали". В поддержку правомерности такого утверждения можно привести немало цитат из лексикона глав исполнительной власти на местах. В частности, Михаил Папиев (эксгубернатор Черновцов) очень часто любил повторять эту мысль, убедительно иллюстрируя ее соответствующими цифрами ${ }^{22}$. В свою очередь, в такой системе финансовых отношений, роль и значение личности местного руководителя сводилась к умению „выбивать” в центре дотации, субвенции и прочие блага, предположительно идущие на развитие данного региона или отдельной его местности. То, что такая схема отношений неустанно плодила не только патрон-клиентские отношения в среде государственной бюрократии и политиков, но и всеохватывающую коррупцию - сегодня общеизвестный факт.

Таким образом, развитие локальной демократии в Украине в целом замерло на долгие годы. Хотя с принятием ряда законов о местном самоуправлении, местных советах, о службе в органах местного самоуправления, ее определенные признаки сохраняются и получают частичное развитие. В частности, в форме общественных слушаний, работы общественных советов и других второстепенных проявлениях местной демократии. Но, как правило, если граждане проявляли несанкционированные властями инициативы, то такие слушания не проводились. Например, в Черновцах Николай Федорук, который был Черновицким главой (мэром) с 1994 до 2011 гг., всего один раз применил такой важный инструмент местной демократии, как общественные слушания по такому принципиально значимому для жизни города вопросу, его бюджету. И это произошло только тогда, когда у него начался конфликт с председателем облгосадминистрации Теофилом Бауэром (кстати, на момент написания текста он был послом Украины в Румынии). Только в этой ситуации Н. Федорук, чтобы опереться в возникшем споре на общественное мнение и показать себя сторонником реформ, провел общественные слушания по местному бюджету г. Черновцы. Т.е., даже непосредственно избираемые горожанами должностные лица в Украине не спешили советоваться со своими избирателями по важнейшим вопросам местного развития без крайних на то причин, как правило, политического характера.

${ }^{22}$ М. Папісв - голова Чернівецької обласної державної адміністраиії, Выступления на расширенном заседании Кабинета министров Украинь,, Урядовий портал, http://www.kmu. gov.ua/control/ru/publish/article?art_id=246100131 (12.11.2015). 
И, собственно говоря, все последующие годы - это был период либо наступления на локальную демократию либо игнорирования потребностей ее развития и укрепления. В качестве основного примера уместно напомнить об обещаниях властей в процессе и сразу же после „Оранжевой революции”. Тогда „вторым пакетом” реформ политической системы Украины (после конституционной реформы), должны были стать системные изменения в местном самоуправлении ${ }^{23}$. Идея изменений заключалась в том, что Украина должна закончить выполнение положений Европейской хартии местного самоуправления и все местные советы обретут необходимую полноту власти ${ }^{24}$. В частности, в соответствии с этой Хартией, они должны получить собственные исполнительные органы, которых у них (районных и областных советов) не было, потому что эту функцию выполняли на разных уровнях соответствующие местные государственные администрации.

Таким образом, основа для развития локальной демократии в Украине было разрушена в институциональном и правовом смыслах. Второй этап конституционной реформы „успешно” провалился, хотя соответствующий законопроект был принят в первом чтении в Верховной Раде, а Конституционный суд Украины дал по нему положительный отзыв. Но победила идея очередной „политической целесообразности”. То есть, политическим силам, которые представляли во власти вообще, и в парламенте в частности, интересы действующего и будущего президентов, было выгодно иметь жесткую, построенную по российскому образцу, вертикаль власти и, таким образом, контролировать всю территорию и население Украины. Что точно не могло быть столь же легко достигнуто в случае воплощения в жизнь реформы исполнительной власти на местах и системы местного самоуправления.

Новая попытка развития локальной демократии приходится уже на период „Революции достоинства” и ее последствий. В Украине сейчас провозглашен процесс децентрализации власти ${ }^{25}$, который проходит под лозунгами возвращения полноты власти местным советам. Но в целом эта реформа пока что больше декларируется, чем осуществляется на практике. Несмотря на то, что есть уже определенные ее концепции ${ }^{26}$, приняты поста-

${ }^{23}$ О. Батанов, Деякі проблеми становлення муніщипальної влади в Україні у контексті конститучійної реформи, „Місцеве самоврядування: пошуки та здобутки”, Київ 2007, с. 234-240.

${ }^{24}$ В. Кравченко, Стан та иляхи подальшої імплементачії Європейської хартії місиевого самоврядування в Украӥні, „Проблеми формування доброчесного, належного місцевого самоврядування", Київ 2008, с. 296-301.

25 О. Скрипнюк, Децентралізачія влади як чинник забезпечення стабільності конституиіийного ладу: теорія й практика, „Віче” 2015, № 12, с. 22-24.

${ }^{26}$ Ю. Шемшученко, Концептуальні проблеми регіональної політики і децентралізації влади в Украйні в контексті євроінтеграційних процесів, „Віче” 2015, № 12, с. 3-6. 
новления Кабинета министров ${ }^{27}$, внесен и рассмотрен в первом слушании пакет конституционных изменений. Правда, рассмотрение последнего в первом чтении 31 августа 2015 года прошло с кровавым инцидентом под стенами ВРУ, в результате чего погибли 4 человека. Я внимательно изучал текст этих документов, недавно докладывал свою точку зрения по этому поводу в Страсбурге на заседании Группы независимых экспертов по Европейской хартии местного самоуправления Конгресса местных и региональных властей Совета Европы. Суть последнего обсуждения может быть сведена к вопросу о том: на самом деле, если эти реформы анализировать, не только в украинском случае, но и в других европейских государствах, то реформы касаются процессов децентрализации или рецентрализации?! Этот вопрос остается открытым для обсуждения и высказывания разных, порой противоположных мнений, по сей день.

В случае с предложенными Президентом Украины Петром Порошенко конституционными изменениями, сторонники точки зрения, что эти изменения направлены на реформу по децентрализации, утверждают, что местные советы получают власть и финансовые ресурсы. А власть префекта, который должен быть представителем центральной государственной власти в регионе, ограничивается только правом вето на принятие решений местными советами ${ }^{28}$. Но есть и противоположная точка зрения. Если рассматривать это право глубже, то исходя из текста законопроекта не понятно, какие у префекта будут основания для использования данного права. В документах написано, что исходя из соображений территориальной целостности и защиты от угроз сепаратизма. Однако, на самом деле, этим права префекта не ограничиваются. Более того, в нынешних документах по децентрализации префект позиционируется более сильной фигурой по отношению к местным органам самоуправления, чем нынешние председатели областных и районных государственных администраций. Объясню, что я имею в виду. Если ныне действующие главы областных и районных государственных администраций назначаются Президентом по предложению Кабинета министров Украины, им же и освобождаются, но на них местные советы могут все же влиять, в частности 2/3 голосов депутатов соответствующего уровня, их могут отправить в отставку. Кандидатура же префекта, в свою очередь, согласно конституционному проекту, предлагается премьер-министром, утверждается или не утверждается Президентом и в дальнейшем его освобождает только Президент. И пока что законопроект предполагает, что больше никто на него повлиять не сможет,

27 Розпорядження Кабінету Міністрів України „Про схвалення Конџепиії реформування місиевого самоврядування та територіальної організації влади”, „Офіційний вісник України” 2014, № 30.

${ }_{28}$ Ю. Шемшученко, Конституиія і виборчий процес в Украйні, „Віче” 2015, № 16, с. 28. 
ни местные советы, ни Кабмин, ни даже суд. Таким образом, префект может стать даже более значительно сильной, во властном отношении фигурой, по сравнению с нынешними руководителями государственных администраций.

Следующий принципиально важный момент - сама суть децентрализации. Для того, чтобы создать надлежащееправовое пространство для развития локальной демократии в Украине, необходимо принять несколько десятков законов. Из них ни один не был принят ко времени написания данной статьи, кроме Закона „О добровольном объединении территориальных общин”. Да и сам данный документ касается самого низового уровня децентрализации - территориальной общины ${ }^{29}$. Хотя при этом украинская власть, по крайней мере, риторически, ориентируются на польский опыт реформ 1989-1999 гг.

Невзирая на такие задержки в осуществлении реформы по децентрализации, как важнейшему условию развития местной демократии, локальная демократия, в отдельных местах, на самом деле получает более широкое развитие в последние годы. Опять же обращусь к опыту Черновцов. Хотя есть и положительный опыт Львова, Луцка и некоторый другой. В контексте подготовки к местным выборам 25 октября 2015 г., в Украине избиратели получили, со стороны тех городских глав, которые хотят быть снова избранными, ряд позитивных новаций. Например, в Черновцах принят новый Устав города ${ }^{30}$, который в том числе включает ряд механизмов непосредственного и более оперативного влияния граждан на местные власти. Это, в частности, и электронные петиции, сборы граждан, обязательность отчета городского главы и депутатов горсовета перед гражданами, механизм инициирования и проведения общественных слушаний и прочее. То есть, ряд возможностей для граждан и механизмов их осуществления там достаточно четко прописан. При этом, например, петиции получили низкий порог их заявителей. Это прогрессивные, но, добавлю, локальные изменения.

Теперь же о недостатках реформы по децентрализации, и, увы, более общих и систематических. Отмечу, что критически оцениваю нововведенную систему выборов в органы местной власти. Прежде всего, в части, касающейся избрания состава местных советов (кроме сельских и поселковых). Получается так, на мой взгляд, что в Украине эта система местных выборов легитимизирует олигархическую модель власти, ибо единственным субъектом выборов состава местных советов становится институт политической партии.

29 О. Батанов, Розвиток конституичійного законодавства про статус територіальних громад в Україні: доктринальні та прикладні аспекти, „Віче” 2015, № 15, с. 18-22.

30 Міська Рада затвердила статут територіальної громади Чернівиів та стратегію розвитку міста, Сайт міста Чернівизі, http://0372.com.ua/miska-rada-zatverdila-statut-teritorialnoyi-gromadi-chernivtsiv-ta-strategiyu-rozvitku (14.11.2015). 
В своем подавляющем большинстве, украинские политические партии не являются ни полноценными институтами социального представительства, ни идеологическими союзами единомышленников. Это, в массе своей, рассчитанные на потребление доверия избирателей бренды, рекламный продукт олигархических групп для достижения собственных личных и узкогрупповых целей. И при этом таком своем состоянии партии сейчас легализованы как единственный легитимный участник выборов, начиная от процесса выдвижения кандидатов в депутаты, продолжая процессом формирования избирательных комиссий, и заканчивая процедурой подсчета голосов избирателей и объявления результатов выборов.

Важно отметить, что новый избирательный закон о местных выборах является довольно-таки откровенно дискриминационным, поскольку парламентские партии имеют больше представителей в избирательных комиссиях, чем внепарламентские партии. Такой закон можно считать результатом корпоративного сговора. Можно высказаться еще более жестко по этому поводу. Понимаю, что в ряде европейских стран действует модель, где партии являются основным игроком избирательного процесса, но для локальной демократии очень важно, чтобы партии не были здесь единственным игроком. В Украине же парадоксальным образом произошло так, что политические партии стали монопольным игроком на поле всего избирательного, да и в немалой степени, политического процесса. Соответственно, сейчас избиратель обладает активным избирательным правом, но практически полностью ограничен в реализации пассивного избирательного права. Потому что быть избранным в местные советы, кроме как сельского и поселкового, он или она не имеют другой возможности, помимо какой-то политической партии. При желании, можно вообще поставить вопрос о правомочности такой избирательной системы, соответственно, она требует радикального и безотлагательного пересмотра. Поэтому, несмотря на ряд властных инициатив, лозунгов по децентрализации, ориентации на польскую и европейскую в целом ее проведения, после определенного периода преувеличенных ожиданий, надежд и требований, сейчас локальная демократия в Украине находится в сложном периоде. А именно в фазе тревожного зависания, возможного попятного развития в направлении рецентрализации, ради решения задач нового этапа восстановления олигархической модели управления страной.

Украина, пережившая бурные события 2004 и 2005 гг. и болезненно переживающая куда более трагичные и кровавые события, начавшиеся с конца 2013 года, смогла избежать модели жесткого авторитаризма по образцу ряда постсоветских стран. В этом большая заслуга ее гражданского общества и определенной части политической элиты. В значительной степени страна успешно преодолевает советское наследие, неспособное отвечать потребностям ее развития и перспективам будущего. Но, как это можно 
увидеть по ряду тенденций внутриполитического процесса и, прежде всего, в сфере развития местной демократии, она снова возвращается к фазе новой легитимации олигархической модели управления государством и его ресурсами. Наверное, олигархическое правление может быть значительно меньшим злом для общества и граждан, чем единоличная или партийная диктатура в централизованном и иерархически организованном государстве, но такое состояние вряд ли уместно отождествлять с полноценной демократией вообще и с местной демократией в частности.

\section{Библиография}

Абрамов В., Демократическая практика российского земства, „Политические исследования" 1995, № 3.

Артемов А., Образ перестройки в офищиальной риторике в 1988-1989 годы на примере выступлений М.С Горбачева, „VECTOR-M” 2014.

Батанов О., Деякі проблеми становлення муніщипальної влади в Україні у контексті конституиійної реформи, „Місцеве самоврядування: пошуки та здобутки”, Київ 2007.

Батанов О., Розвиток конституційного законодавства про статус територіальних громад в Украӥні: доктринальні та прикладні аспекти, „Віче” 2015, № 15.

Ганшина К., Становлення $i$ розвиток системи місиевого самоврядування у незалежній Україні: від авторитаризму до демократії, „Збірник наукових праць Харківського національного педагогічного університету імені Г. С. Сковороди" 2010, Серія 39.

Герасименко Г., История земского самоуправления, Поволжская академия гос. службы, 2003.

Губань Р., Правове регулювання становлення сучасного адміністративнотериторіального устрою (від Київської Русі до Гетьманщини), „Науковий вісник Академії муніципального управління" 2009, Вип. 2.

Гураль П., Міські та волосні громади - активні учасники політичного життя Київської Русі, „Вісник Львівського університету. Серія юридична” 2011, Вип. 52.

Долженков О., „Політологічні записки” 2013, № 7, http://nbuv.gov.ua/j-pdf/ Polzap_2013_7_5.pdf (13.11.2015).

Иванченко А., А. Любарев, Российские выборы от перестройки до суверенной демократии, Москва 2007.

Кармазіна М., Демократи, соиіалісти ци ,третя сила” у боротьбі за владу (19911994 рр.), „Політичний менеджмент” 2005, № 6.

Кравченко В., Стан та шляхи подальшої імплементації Європейської хартії місиевого самоврядування в Украӥні, „Проблеми формування доброчесного, належного місцевого самоврядування", Київ 2008.

Кузьменко Ю., Партійно-радянська номенклатура в умовах суверенізаиії УРСР (березень 1990-серпень 1991 рр.), „Український історичний журнал” 2013, № 4. 
М. Папієв - голова Чернівецької обласної державної адміністрації, Выстулпления на расширенном заседании Кабинета министров Украины, Урядовий портал, http://www.kmu.gov.ua/control/ru/publish/article?art_id=246100131 (12.11.2015).

Макушина Г., Політична та правова культура населення Гетьманщини ХVIII cm. y сучасній історіографї, „Наукові праці Миколаївського державного гуманітарного університету імені Петра Могили" 2008, Вип. 75.

Міська Рада затвердила статут територіальної громади Чернівців та стратегію розвитку міста, Сайт міста Чернівиі, http://0372.com.ua/miska-rada-zatverdilastatut-teritorialnoyi-gromadi-chernivtsiv-ta-strategiyu-rozvitku (14.11.2015).

Муравський О., Виборча кампанія 1990 року до Верховної Ради УРСР та місиевих органів влади: особливості Західноукраӥнського регіону, „Україна: культурна спадщина, національна свідомість, державність" 2013, Вип. 23.

Нестеров А., Австро-Венгрия как интеграџионный проект: опыт для ЦентральноВосточной Европь XXI в., „Известия Уральского федерального университета”, Общественные науки, 2013, Серия 3.

Олійник О., Урядування” в літописній традиції Київської Русі, Збірник наукових праць НАДУ, http://www.nbuv.gov.ua/e-journals/DUTP/2011_2/txts/Oliynyk. Pdf (12.11.2015).

Олуйко М., Олуйко В., Украӥна на шляху до держави самоврядних територіальних громад, „Університетські наукові записки” 2005, № 1-2.

Пальшков К., Легіслатури Л. М. Кравчука та Л. Д. Кучми як період становлення та затвердження авторитарного іміджу українського президентства, „Актуальні проблеми політики” 2013, Вип. 50.

Полещенко Д., Государственная власть и местное самоуправление в Российской империи и Российской Федеращии, „Журнал российского права” 2010, № 11.

Райковський Б., Взаємодія виборчої та партійної систем: вітчизняний досвід, „Наукові праці Чорноморського державного університету імені Петра Могили” 2010, Вип. 112.

Розпорядження Кабінету Міністрів України ,Просхвалення Концеепціїреформування місиевого самоврядування та територіальної організащії влади”, „Офіційний вісник України” 2014, № 30.

Скрипнюк О., Децентралізація влади як чинник забезпечення стабільності конституційного ладу: теорія й практика, „Віче” 2015, № 12.

Согрин В., Перестройка: итоги и уроки, „Общественные науки и современность” 1992, № 1.

Сухорукова А., Обласні державні адміністрації: становлення та тенденції розвитку, „Теорія та практика державного управління” 2010, № 3 .

Шановська О., Інтелігенція і влада в Украӥні доби Перебудови: проблема взаємовідносин, „Наукові записки Вінницького державного педагогічного університету імені Михайла Коцюбинського. Серія: Історія” 2009, № 15.

Шейнис В., Большевистская власть и первая советская Конституция, „Общественные науки и современность” 2012, № 1.

Шемшученко Ю., Конституція $і$ виборчий прочес в Украӥні, „Віче” 2015, № 16.

Шемшученко Ю., Конщептуальні проблеми регіональної політики і децентралізації влади в Украӥні в контексті євроінтеграџійних процесів, „Віче” 2015, № 12. 
Anatolij Krugłaszow

\section{Ukraińska demokracja lokalna: Od radzieckiej spuścizny w stronę modelu europejskiego}

W artykule analizowane są wybrane węzłowe problemy i tendencje, odnoszące się do skomplikowanego procesu kształtowania się demokracji lokalnej na Ukrainie. Autor zwraca szczególną uwagę na jej genezę i początkowy etap rozwoju, tj. od momentu reform Michaiła Gorbaczowa w ZSRR, podnosi także kwestię zależności pomiędzy rozwojem demokracji lokalnej na Ukrainie a ewolucją ukraińskiego systemu wyborczego. W artykule odnotowuje się obecność zjawiska stagnacji rozwoju demokracji lokalnej w pewnych okresach po odzyskaniu przez Ukrainę niepodległości. Wiele uwagi poświęca się krytycznej ocenie treści i konsekwencjom dotychczasowych prób decentralizacji władzy na Ukrainie. Autor rozpatruje zasadnicze wady nowego modelu wyborów lokalnych, stosowanego na Ukrainie od październiku 2015 r. Wskazano także na zagrożenia stojące przed Ukrainą w trakcie dalszych reform politycznych.

Słowa kluczowe: Ukraina, demokracja lokalna, Związek Radziecki, europeizacja

Anatolij Krugłaszow

\section{Ukrainian Local Democracy: From the Soviet Heritage to European Model}

The article considers some leading tendencies, which are related to the process of Ukrainian local democracy formation. The key stages of the process are distinguished since the reforms of M. Gorbachev. Author points out at some connotations of electoral system evolution and the process of local democracy development. Some hardships and stagnation with regard to lowest level of democratic process are stated also. Main focus is made on recent reforms of decentralization and its characteristic are outlined. The newest model of local elections of 2015 is put under certain scrutiny and main errors of the models highlighted. Some challenges of delaying the reforms of Ukrainian political system have been analyzed too.

Keywords: Ukraine, local democracy, Soviet Union, Europeanisation 